\title{
Does Nursing Education in Turkey Affect the Attitudes Toward Ageing and Elderliness?
}

\author{
By Sadık Hançerlioğlu ${ }^{*}$ Ísmail Toygar ${ }^{ \pm} \&$ Dimitrios Theofanidis
}

\begin{abstract}
The aim of this study is to explore the attitudes of nurse students in Turkey, towards ageing and elderliness and to determine differences in terms of year of study. The study uses a comparative design with data collected from February to March 2020. A random sample of 306 nursing students was selected. A demographic data form and the Attitudes toward Ageing and Elderliness Scale (ATAES) were used to collect data. Of the students, $47.7 \%$ reported that they cared for older adults in their clinical practice and $53.6 \%$ confirmed that they had successfully completed the theoretical lessons on elderly care. Theoretical education (Hedge's $g=0.23$ ) and clinical practice (Hedge's $g=0.34$ ) on elderly care have minimal effects on the attitudes toward ageing and elderliness. Theoretical education and clinical practice as conducted currently in a university in Turkey, failed to improve attitudes toward ageing and elderliness.
\end{abstract}

Keywords: ageing, elderliness, nursing, nursing education, nursing students

\section{Introduction}

Ageing is a natural biological process of life that starts in the womb and ends with death (Craik and Salthouse 2011). Elderliness is a distinctive period of later life with specific characteristics (Hakverdioğlu Yönt et al. 2015). However, the terms ageing and elderliness have a negative image in many societies. Although the term "elderliness" may be associated with many positive terms such as kindness, wisdom, dependability, affluence, freedom, political power, eternal youth, and happiness in the community, it may also refer to negative terms such as illness, uselessness, asexuality, declining mental functions, isolation, poverty, and depression (Palmore 1999).

Ageing and progressive physical degeneration can easily lead to prejudice or discrimination against older adults in the community. So, the younger generation may fear ageing and consider elderliness in a negative light both for themselves and others (Bousfield and Hutchison 2010, Meisner 2012). These prejudices on ageing and elderliness feed and enhance ageism (Bergman et al. 2013).

The World Health Organization (WHO) defines ageism as stereotyping and discriminating against people according to their age and approaching and categorizing them with prejudice (WHO 2020). Ageism has harmful effects on the overall wellbeing of older adults (Nelson 2016, Gendron et al. 2016). Moreover, in these adults, ageism can cause resistance for help from others and this further

\footnotetext{
*Research Assistant Doctor, Internal Medicine Nursing Department, Faculty of Nursing, Ege University, Turkey.

${ }^{ \pm}$Research Assistant Doctor, Internal Medicine Nursing Department, Faculty of Nursing, Ege University, Turkey.

Associate Professor, Nursing Department, International Hellenic University, Greece.
} 
speed their decline in health. The literature refers to this phenomenon as "social death" (Seale 1996).

The attitudes of nurses towards ageing and elderliness are of vital importance as they are the health care professionals in most frequent contact with older patients. A Canadian projection anticipates that up to $75 \%$ of nurses' time will be spent on older adults in the near future (Holroyd et al. 2009). Yet, a systematic review by Khodabandeh et al. (2018) on elderly health care in Iran identified ten items which pose age-related challenges i.e., negative attitudes of nurses in aged care; lack of appropriate national programs for the care of the elderly; lack of knowledge and lack of standard care plans; undiagnosed chronic diseases; lack of adherence to treatment; irregular drug use depression; malnutrition; isolation from family and society and perceived misbehavior.

Therefore, in order to support and protect vulnerable older adults from the harmful effects of ageism, it is essential to improve both the staff nurses and nursing students' attitudes toward ageing and elderliness.

The majority of nursing curricula worldwide include modules on this subject focusing mainly on prevention and treatment of diseases in old people's care. These include social gerontology, psychology, social work, legal aspects, ethics, and more. However, because of the nature of the profession, in some cases staff and students may already have attained negativity towards caring for older people. Such attitudes may be due to social, psychological and physical features associated with elder clients. Thus, embracing positive attitudes towards the elderly should be of major focus in geriatric nursing education (Perez et al. 2016).

However, Holroyd et al. (2009) found that in the second and fourth year of nursing studies, positive attitudes toward ageing decreased whereby negative attitudes increased. Furthermore, a study in Spain by Sarabia-Cobo and Pfeiffer (2015) reported that there was a high prevalence of negative stereotypes toward ageing among student nurses. In contrast, Gonçalves et al. (2011) showed that nursing students' attitudes toward ageing and older adults are more positive when compared with psychology students. Moreover, their study also indicated that student nurses had a greater interest in working with older adults than psychology and social work students. Therefore, whether a change in nursing education approach can improve and sustain positivism towards the aged, remains unclear.

The aim of this study is to explore the attitudes of nurse students towards ageing and elderliness and to determine differences in terms of year of study.

\section{Literature Review}

Nursing is an occupation that emerged as a result of the need for care of patients, almost as old as human history (Egenes 2017). The most important element that gives a professional identity to a profession is vocational education (Jackson 2017). Education is the main factor to become a qualified nurse (Kermansaravi et al. 2015). The positive effect of nursing care on the treatment process has been proven by scientific research; as the quality of education increases, the quality of care increases (Karaca and Durna 2019). 
Nursing education in Turkey has made significant progress over the decades. Besim Ömer Pasha, who was the first military physician in Turkey, decided to apply the method used in the training of female nurses in Japan in Istanbul and invited the daughters of well-known families of the city to the "Voluntary Nursing Course". This course was the first nursing education in Turkey. In 1925, the Red Crescent Nursing School was established under the Red Crescent Association. In the following years, schooling in nursing progressed very slowly and in 1960, the Ministry of Health started to open Health Vocational High Schools. Since 1961, there has been an increase in nursing education institutes. The number of health vocational high schools has increased rapidly, thus meeting the workforce need in hospitals (Kocaman and Yürümezoğlu 2015, Ulusoy 1998, Bahçecik and Alpar 2009).

The nursing education in higher education first started with Ege University School of Nursing in 1955, followed by Hacettepe University and Istanbul University Florence Nightingale School of Nursing in 1961. The number of nursing undergraduate programs in Turkey until 1995 was only 11. However, in 1996, with the closure of high schools giving nursing education, the number of nursing undergraduate programs increased from 11 to 70 overnight (Kocaman and Yürümezoğlu 2015). Since then, the number of schools and students has continued to increase in a way that is not compatible with the infrastructure of the schools and the number of educators. This increase has brought with it concerns due to conditions such as the lack of academic staff and infrastructure that may adversely affect the quality of education (Ulusoy 1998).

Nursing education need to adapt to the changing world to meet the people's demands. In recent decades, elderly population is increasing in Turkey and world. This increase causes various problems in economic, social, and family life. These problems can also affect health services, health expenditures, health insurance institutions, and occupational care. Older people may be considered as a social and economic burden by society. As a social consequence of the elderly people encountering these problems, negative attitudes towards elderly people can be developed (Ergöl 2011). The attitude of the health professionals, especially nurses which is the main profession caring for older adults, towards the elderly is as important as the society's attitude towards the elderly and aging. Because, with the prolongation of life span, management of chronic diseases and increased access to health services, and the increase in the education level of the society, the use of health services by the older adults has increased in recent decades and it is projected that it will continue to increase in the future (McKinlay and Cowan 2006, Bujnowska-Fedak and Pirogowicz 2014, Ren et al. 2019).

The attitudes of nurses, who are the most populous occupational group in health care, toward aging and elderliness has gain more importance in recent decades with the increase of the elderly population in society. İt is projected that nursing students, as a potential member of the profession in the future, will generally care for older adults in the near future. Zing et al. reported that students who do not have sufficient theoretical knowledge and experience in elderly care will be less willing to care for older adults. In addition, Liu et al. (2013) 
determined that being knowledgeable about old age and preferring to work with elderly people are related to a positive attitude towards elderly people.

Although nursing students have a positive attitude while providing care to the elderly and having sufficient knowledge about the old age period is important in this respect, nursing education programs and institutions can play an important role in nursing students' development of positive attitudes towards aging and aging (Kulakçı 2010).

\section{Methodology}

\section{Setting and Sample}

This is a cross-sectional comparative study with nursing students 18 years and older, studying at grades from $1^{\text {st }}$ to $4^{\text {th }}$ year. It was conducted in a nursing faculty of a public university in Turkey. Cohen's criteria were used to calculate the sample size (Daniel and Cross 2018). The total number of students enrolled in the faculty was 1136. According to this criterion, sample size was calculated to be 287 students ( $95 \%$ confidence interval, $\alpha=0.05, \mathrm{~d}=0.05, \mathrm{p}=0.50$, and $\mathrm{q}=0.5$ ) who were randomly selected. The study was terminated after the sample reached 306 participants.

\section{Data Collection}

Data were collected from February to March 2020 and were based on selfreported answers. An extended demographic data form and the Attitudes toward Ageing and Elderliness Scale (ATAES) were used to collect data.

\section{Extended Demographic Data Form}

This form was developed by researchers and consisted of 11 items, collecting information on individuals' age, gender, year of study, marital status, family characteristics, and general views on older adults.

\section{Attitudes toward Ageing and Elderliness Scale}

The scale was developed in Turkey by Otrar in 2016 to assess the attitudes toward ageing and elderliness. The scale consists of 45 items and 4 subscales including difficulty to accept old age, perception of social attrition, difficulty to cope with life, and negative image. In terms of scale grading, a high subscale and total score, indicate more positive attitudes toward ageing and elderliness. The scale was reported as valid and reliable for those 18 years and older. Chronbach's alpha value was 0.97 . Test-retest correlations were also significant for the total score, i.e., $r=0.89 ; p<0.001$. Item analysis showed that all values were determined significant and discriminant analysis verified the scale to be discriminative. Therefore, the scale is valid and reliable for research in Turkey and hence was chosen for this study's needs (Otrar 2016). 


\section{Data Analysis}

Data analysis was performed using IBM SPSS version 25.0. The descriptive data in the study are presented as numbers (n) and percentages (\%). Prior to data analysis, raw data were examined to determine if there was a normal distribution; this informed the decision regarding whether to use parametric or nonparametric statistics. A Chi-square test for independence was used to test the differences in categorical groups including gender, marital status, years in nursing education, willingness to care for older adults, and to live with older relatives. The MannWhitney test was applied to compare attitudes between student groups for nonparametric data and t-test was applied for parametric data. One-Way ANOVA was used for multigroup comparations. Post-hoc effects were examined using the Dunn test. Regression analysis was used to estimate the effects of variables on the ATAES total mean scores.

\section{Ethics and Deontology}

Written approval to conduct the study was obtained from relevant University Scientific Research and Publication Ethics Committee (protocol number 02/05), from relevant University Nursing Faculty and from the participants. Participants' anonymity and data confidentiality were also secured. All directives of the Helsinki Declaration have been followed.

\section{Results}

The majority of the students were female $(90.5 \%)$ with a mean age of $21.4 \pm$ 1.2 years; $47.7 \%$ of the sample reported that they cared for older adults in their clinical practice and $53.6 \%$ confirmed that they had successfully completed the theoretical lessons on elderly care. Of the students, $26.8 \%$ were studying in their $4^{\text {th }}$ year, $61.8 \%$ were reported they are willing to care for older adults after their graduation, $48.7 \%$ were living with one or more older adults in the same house, and $60.5 \%$ reported that they want to live with younger family member in the same house when they get old (Table 1).

Statistically significant differences were found with regard to mean scores of perceptions on social attrition $(p=0.005)$, difficulty to cope with life $(p=0.001)$, negative images $(p=0.002)$ subscales, and ATAES total score $(p=0.004)$ between students who care for older people or did not. Statistically significant differences were found with regard to all mean points of subscales and total of ATAES between the students who successfully completed the theoretical lessons on elderly care and those who did not. There were no statistically significant differences with regards to years in nursing education and overall scores (Table 2). 
Vol. 8, No. 4 Hançerlioğlu et al.: Does Nursing Education in Turkey Affect the Attitudes...

Table 1. Distribution of Sociodemographic and Education-Related Characteristics of Students

\begin{tabular}{|c|c|c|}
\hline & $\mathbf{n}$ & $\%$ \\
\hline \multicolumn{3}{|l|}{ Gender } \\
\hline Female & 277 & 90.5 \\
\hline Male & 29 & 9.5 \\
\hline \multicolumn{3}{|c|}{ Years in Nursing Education } \\
\hline $1^{\text {st }}$ year & 67 & 21.9 \\
\hline $2^{\text {nd }}$ year & 79 & 25.8 \\
\hline $3^{\text {rd }}$ year & 78 & 25.5 \\
\hline $4^{\text {th }}$ year & 82 & 26.8 \\
\hline \multicolumn{3}{|c|}{ Family Structure } \\
\hline Nuclear & 239 & 78.1 \\
\hline Extended & 59 & 19.3 \\
\hline Other & 8 & 2.6 \\
\hline \multicolumn{3}{|c|}{ Living with older adults } \\
\hline Yes & 149 & 48.7 \\
\hline No & 157 & 51.3 \\
\hline \multicolumn{3}{|c|}{ Willingness to care for older adults } \\
\hline Yes & 189 & 61.8 \\
\hline No & 117 & 38.2 \\
\hline \multicolumn{3}{|c|}{ Want to live with younger family members when they get old } \\
\hline Yes & 185 & 60.5 \\
\hline No & 121 & 39.5 \\
\hline \multicolumn{3}{|c|}{ Completed the theoretical lessons on elderly care } \\
\hline Yes & 164 & 53.6 \\
\hline \multirow[t]{2}{*}{ No } & 142 & 46.4 \\
\hline & \multicolumn{2}{|c|}{ Mean \pm SD } \\
\hline Age & \multicolumn{2}{|c|}{$21.4 \pm 1.2$} \\
\hline
\end{tabular}

Table 2. Comparison of ATAES Mean Points with regards to Groups

\begin{tabular}{|c|c|c|c|c|c|c|}
\hline & & $\begin{array}{c}\text { Difficulty } \\
\text { to accept } \\
\text { old age }\end{array}$ & $\begin{array}{c}\text { Perception of } \\
\text { social } \\
\text { attrition }\end{array}$ & $\begin{array}{l}\text { Difficulty } \\
\text { to cope } \\
\text { with life }\end{array}$ & $\begin{array}{c}\text { Negative } \\
\text { image }\end{array}$ & $\begin{array}{c}\text { ATAES } \\
\text { Total }\end{array}$ \\
\hline \multirow{4}{*}{$\begin{array}{l}\text { Cared for older } \\
\text { people in } \\
\text { clinical practice }\end{array}$} & Yes & $\begin{array}{c}34.92 \pm \\
9.98 \\
\end{array}$ & $43.21 \pm 9.27$ & $\begin{array}{c}33.08 \pm \\
7.78 \\
\end{array}$ & $\begin{array}{c}23.37 \pm \\
5.28 \\
\end{array}$ & $\begin{array}{c}134.58 \pm \\
30.25 \\
\end{array}$ \\
\hline & No & $\begin{array}{c}32.88 \pm \\
8.84 \\
\end{array}$ & $40.23 \pm 9.08$ & $\begin{array}{c}29.97 \pm \\
8.51 \\
\end{array}$ & $\begin{array}{c}21.56 \pm \\
4.98 \\
\end{array}$ & $\begin{array}{c}124.65 \pm \\
29.08 \\
\end{array}$ \\
\hline & $\mathrm{p}$ & 0.061 & 0.005 & 0.001 & 0.002 & 0.004 \\
\hline & Hedge's g & 0.22 & 0.32 & 0.38 & 0.35 & 0.34 \\
\hline \multirow{4}{*}{$\begin{array}{l}\text { Completed the } \\
\text { theoretical } \\
\text { lessons on } \\
\text { elderly care }\end{array}$} & Yes & $\begin{array}{c}35.10 \pm \\
9.52\end{array}$ & $43.03 \pm 9.07$ & $\begin{array}{c}32.24 \pm \\
8.06\end{array}$ & $\begin{array}{c}23.14 \pm \\
5.17\end{array}$ & $\begin{array}{c}133.51 \pm \\
29.69\end{array}$ \\
\hline & No & $\begin{array}{c}32.95 \pm \\
9.41 \\
\end{array}$ & $40.73 \pm 9.37$ & $\begin{array}{c}32.09 \pm \\
8.42 \\
\end{array}$ & $\begin{array}{c}21.98 \pm \\
5.21 \\
\end{array}$ & $\begin{array}{c}126.74 \pm \\
30.14 \\
\end{array}$ \\
\hline & $\mathrm{p}$ & 0.048 & 0.030 & 0.223 & 0.041 & 0.049 \\
\hline & Hedge's g & 0.23 & 0.25 & 0.02 & 0.22 & 0.23 \\
\hline \multirow{6}{*}{$\begin{array}{l}\text { Years in } \\
\text { Nursing } \\
\text { Education }\end{array}$} & $1^{\text {st }}$ year & $\begin{array}{c}34.57 \pm \\
9.20 \\
\end{array}$ & $42.30 \pm 9.26$ & $\begin{array}{c}32.14 \pm \\
8.36 \\
\end{array}$ & $\begin{array}{c}22.69 \pm \\
5.14\end{array}$ & $\begin{array}{c}131.70 \pm \\
29.83 \\
\end{array}$ \\
\hline & $2^{\text {nd }}$ year & $\begin{array}{c}35.54 \pm \\
9.82\end{array}$ & $43.66 \pm 8.93$ & $\begin{array}{c}32.33 \pm \\
7.85\end{array}$ & $\begin{array}{c}23.53 \pm \\
5.59\end{array}$ & $\begin{array}{c}135.05 \pm \\
29.67\end{array}$ \\
\hline & $3^{\text {rd }}$ year & $\begin{array}{c}32.44 \pm \\
9.46 \\
\end{array}$ & $39.82 \pm 9.00$ & $\begin{array}{c}30.18 \pm \\
7.94 \\
\end{array}$ & $\begin{array}{c}21.58 \pm \\
5.14 \\
\end{array}$ & $\begin{array}{c}124.01 \pm \\
29.03 \\
\end{array}$ \\
\hline & $4^{\text {th }}$ year & $\begin{array}{c}33.44 \pm \\
9.40 \\
\end{array}$ & $41.59 \pm 9.69$ & $\begin{array}{c}31.95 \pm \\
8.81 \\
\end{array}$ & $\begin{array}{c}22.35 \pm \\
5.28 \\
\end{array}$ & $\begin{array}{c}129.33 \pm \\
31.12 \\
\end{array}$ \\
\hline & $\mathrm{p}$ & 0.194 & 0.073 & 0.343 & 0.128 & 0.134 \\
\hline & Cohen's f & 0.14 & 0.46 & 0.30 & 0.31 & 0.74 \\
\hline
\end{tabular}


Regression analysis was used to estimate the effects of variables on the mean of ATAES total scores. Care of older adults in clinical practice and completion of the theoretical lessons on elderly care were negatively affecting the mean of ATAES total score (Table 3).

According to Hedge's g calculation for the independent sample t-test; care for older adults in clinical practice has a small effect on attitudes toward ageing and elderliness (Hedge's $g=0.34$ ). Completion of the theoretical lessons on elderly care has also a small effect on attitudes toward ageing and elderliness (Hedge's $\mathrm{g}=$ $0.23)$.

Table 3. Regression Estimates on Mean of ATAES Total Scores

\begin{tabular}{|l|c|c|c|c|c|c|}
\hline & \multicolumn{1}{|c|}{$\mathbf{B}$} & $\begin{array}{c}\mathbf{9 5 \%} \text { CI } \\
\text { for B } \\
\text { Lower } \\
\text { Bound }\end{array}$ & $\begin{array}{c}\mathbf{9 5 \%} \text { CI } \\
\text { for B } \\
\text { Upper } \\
\text { Bound }\end{array}$ & $\boldsymbol{\beta}$ & $\mathbf{t}$ & $\mathbf{p}$ \\
\hline Constant & 165.13 & 148.22 & 182.05 & & 19.21 & $<0.001$ \\
\hline $\begin{array}{l}\text { Cared to older adults in } \\
\text { clinical practice }\end{array}$ & -13.02 & -19.94 & -6.107 & - & -3.71 & $<0.001$ \\
\hline $\begin{array}{l}\text { Completed the } \\
\text { theoretical lessons on } \\
\text { elderly care }\end{array}$ & -10.57 & -17.48 & -3.67 & - & -3.01 & 0.003 \\
\hline
\end{tabular}

\section{Discussion}

Positive attitudes by nursing students towards ageing and elderliness are important to maintain. Nursing education already incorporates modules relating to ageing and elderliness. Yet, there are conflicting results reported in the literature on the effects of nursing education on attitudes toward ageing and elderliness (Holroyd et al. 2009, Gonçalves et al. 2011). This study has explored this relatively poorly researched topic.

In this study, the Attitudes toward Ageing and Elderliness Scale (ATAES) was used to explore and determine the nursing students' attitudes. Results showed that more than half of the sample reported that they were willing to work in health care centers for older adults. Yet, in the relevant literature, the willingness to care for older adults among nursing students was reported to vary widely. Many personal factors are affecting the willingness to care for older adults such as salary and career opportunities (Toygar and Karadakovan 2020, Zhang et al. 2016, Chi et al. 2016, Rathnayake et al. 2016).

One of the attributes affecting attitudes toward ageing and elderliness was the experience of caring for older adults in clinical practice. The students who cared for older adults in clinical practice showed more negative attitudes toward ageing and elderliness. In usual clinical practice, students mostly care for older adults who have at least one disease or symptom (Mauk 2010). So, they are more exposed to the negative changes that can arise from ageing. It is possible that exposure to these negative changes can place nurses more at risk of developing further negative attitudes toward ageing and elderliness. 
In the current study, a factor that seemed to promote negative attitudes toward ageing and elderliness was the successful completion of the theoretical modules on elder people's care. Thus, these theoretical lessons on elderly care may seem not to serve their purpose and facilitate positiveness toward ageing and elderliness. Similar to clinical practice, negative changes towards the old can be observed, i.e., the more a student is exposed to first-hand care for the old, the more negative they become towards working for/with this age group (Perez et al. 2016, Deschodt et al. 2010). Therefore, it seems that both theoretical preparation and clinical experience in nurse students in this study, failed in the purpose to produce more positive attitudes towards the aged. This suggests an unfortunate shortcoming in contemporary nursing education in Turkey whereby there is a need for more structuralized forms of older people's care, both theoretical and practical, in the undergraduate nursing courses. There is a need for investigative research into the exact competencies which would promote a shift from ageism to pro-age.

It is noteworthy that a way to tackle ageism via education is to confront elements of ageism such as 'group think' of negative stereotypes toward ageing among nursing students. Such an endeavor, is a Nursing Course on Ageing, as delivered by Sarabia-Cobo and Pfeiffer (2015) who showed that proper training of future professionals markedly contributes in the dispensation of proper care and the diminishing of ageism, which they endorse remains prevalent in healthcare systems.

Along these lines, Meriç et al. (2019) also noticed that positive attitudes toward the elderly should be promoted in Turkey. Thus, they recommend that geriatric nursing and home care nursing lectures be included in the nursing education curricula including awareness of the importance of the concept of old age and elderly care.

Yet, not all research is claiming that there is a widespread ageism in situ among student nurses. Usta et al. (2012) students who completed classes related to elderly health and either lived with or planned to live with at least one elderly parent after starting a family or already experienced having an elderly relative in their home, tended to have positive attitudes toward ageing. Furthermore, Söylemez et al. (2018) in their cross-sectional study on students' attitudes towards old people found slightly positive attitudes on average, but they still recommended that nursing curricula should include more geriatric courses in order to create further awareness and knowledge regarding care of elderly and more positive attitudes toward the elderly.

There was no statistically significant difference with regards to years in nursing education and overall scores in this study. Yet, our results also suggested that negative attitudes increased in the second and fourth years of education but these were not statistically significant. These are the time spans which coincide with the delivery of theoretical education and practice on elderly care in the faculty where this study was conducted.

Although the mean scores of ATAES were lower in the fourth year compared to the first year, theoretical education and clinical practice of nursing students showed only small effects on attitudes toward ageing and elderliness. Demir et al. (2016) also found that elder discrimination was defined by academic class level, 
and the willingness to work with old people. They also suggest that more educational elements on getting old and declining/maintaining health should be incorporated in the nursing curricula. More gerontology lessons need to be added into undergraduate programs and practice areas enabling students to spend more time with elderly. Finally, training and consulting programs about discrimination against the old need to be created for the students in all stages of their education.

It is also recommended in the international literature that visiting nursing homes and seeing healthy older adults decreases ageism among nursing students (Deschodt et al. 2010). Smith et al. (2017) also suggest that increased exposure to and interactions with older adults can reduce ageist views among college students. It is therefore postulated that such targeted actions may influence nurse students in adopting more positive approaches to ageing and elderliness.

\section{Limitations}

The study was conducted in only one nursing faculty in the country and thus, results cannot be generalized to a national level.

\section{Conclusion}

As a result, nursing education does not seem to affect the attitudes toward ageing and elderliness at least to a degree that it was planned to achieve. Unfortunately, as this sample indicates that, theoretical education and clinical practice as conducted currently in a university in Turkey, failed to improve attitudes toward ageing and elderliness. We propose that nursing students should be exposed to healthy older adults more frequently and that in the theoretical training, targeted educational techniques and content are employed in order to strive towards positive changes on ageing. The need for further investigative studies into the exact nature of the competencies which would promote a shift from reported ageism to pro-age is of paramount nursing importance.

Overall, adopting positive attitudes towards the elderly would translate into providing higher quality nursing care for the elderly, and raising the standards of the nursing profession as a whole.

\section{References}

Bahçecik N, Alpar ŞE (2009) Nursing education in Turkey: from past to present. Nurse Education Today 29(7): 698-703.

Bergman YS, Bodner E, Cohen-Fridel S (2013) Cross-cultural ageism: ageism and attitudes toward aging among Jews and Arabs in Israel. International Psychogeriatrics 25(1): 6-15.

Bousfield C, Hutchison P (2010) Contact, anxiety, and young people's attitudes and behavioral intentions towards the elderly. Educational Gerontology 36(6): 451-466. 
Bujnowska-Fedak MM, Pirogowicz I (2014) Support for e-health services among elderly primary care patients. Telemedicine and E-Health 20(8): 696-704.

Chi MJ, Shyu ML, Wang SY, Chuang HC, Chuang YH (2016) Nursing students' willingness to care for older adults in Taiwan. Journal of Nursing Scholarship 48(2): 172-178.

Craik FIM, Salthouse AS (2011) The handbook of ageing and cognition. Psychology Press.

Daniel WW, Cross CL (2018) Biostatistics: a foundation for analysis in the health sciences. Wiley.

Demir G, Bicer S, Bulucu-Böyüksoy D, Özen B (2016) Attitudes of Nursing Students about Ageism and the Related Factors. International Journal of Caring Sciences 9(3): 900-908.

Deschodt M, de Casterlé BD, Milisen K (2010) Gerontological care in nursing education programmes. Journal of Advanced Nursing 66(1): 139-148.

Egenes KJ (2017) History of nursing. In Issues and Trends in Nursing: Essential Knowledge for Today and Tomorrow, 1-26.

Ergöl Ş (2011) Nursing education in higher education in Turkey. Journal of Higher Education and Science 1(3): 152-155.

Gendron TL, Welleford EA, Inker J, White JT (2016) The language of ageism: why we need to use words carefully. The Gerontologist 56(6): 997-1006.

Gonçalves DC, Guedes J, Fonseca AM, Pinto FC, Martín I, Byrne GJ et al. (2011) Attitudes, knowledge, and interest: preparing university students to work in an aging world. International Psychogeriatrics 23(2): 315-321.

Hakverdioğlu Yönt G, Akın Korhan E, Dizer B (2015) Nursing students' perceptions of elderly and elderliness. Anatolian Journal of Clinical Investigation 9(1): 195-199.

Holroyd A, Dahlke S, Fehr C, Jung P, Hunter, A (2009) Attitudes toward aging: implications for a caring profession. Journal of Nursing Education 48(7): 374-380.

Jackson D (2017) Developing pre-professional identity in undergraduates through workintegrated learning. Higher Education 74(5): 833-853.

Karaca A, Durna Z (2019) Patient satisfaction with the quality of nursing care. Nursing Open 6(2): 535-545.

Kermansaravi F, Navidian A, Yaghoubinia F (2015) Nursing students' views of nursing education quality: a qualitative study. Global journal of health science 7(2): 351.

Khodabandeh S, Dehghan N, Abazari F, Pouraboli B (2018) Challenges in carıng for the elderly in Iran: a systematic review. Ethiopian Medical Journal 56(2): 189-196.

Kocaman G, Yürümezoğlu HA (2015) Situation analysis of nursing education in Turkey: Nursing education with numbers (1996-2015). Journal of Higher Education and Science 5(3): 255-262.

Kulakçı H (2010) Hemşirelik lisans programı birinci ve dördüncü sınıf öğrencilerinin yaşl1lık ve yaşlanmaya ilişkin düşüncelerinin ve görüşlerinin değerlendirilmesi (Evaluation of nursing students' ideas and views about old age and ageing in the first and fourth year of baccalaureate program in nursing). DEUHYOED 3(1): 15-22.

Liu Y, Norman IJ, While AE (2013) Nurses' attitudes towards older people: a systematic review. International Journal of Nursing Studies 50(9): 1271-1282.

Mauk KL (2010) Gerontological nursing: competencies for care. Jones \& Bartlett Publishers.

McKinlay A, Cowan S (2006) "If you're frail you've had it": A theory of planned behavior study of student nurses' attitudes towards working with older patients. Journal of Applied Social Psychology 36(4): 900-917.

Meisner BA (2012) Physicians' attitudes toward ageing, the aged, and the provision of geriatric care: A systematic narrative review. Critical Public Health 22(1): 61-72. 
Meriç M, Ergün G, Pola G, Dölek M, Dikmen B, Yılmaz U (2019) Relationship between nursing students' attitudes toward elderly discrimination and opinions about home care services. Home Health Care Management \& Practice 31(4): 219-223.

Nelson TD (2016) Promoting healthy aging by confronting ageism. American Psychologist 71(4): 276-282.

Otrar M (2016) Yaşl1lik ve yaşlanmaya ilişkin tutum ölçeği: geçerlik ve güvenirlik çalışması (An attitude scale toward aging and elderliness: a validity and reliability study). İstanbul Üniversitesi Sosyoloji Dergisi 36(2): 527-550.

Palmore EB (1999) Introduction and basic definitions-type of ageism. Ageism: negative and positive. $2^{\text {nd }}$ Edition. New York: Springer Publishing Company.

Perez CFDA, Tourinho FSV, Carvalho Júnior PM (2016) Competencies in the nurse education process to care for the aging: an integrative review. Texto \& ContextoEnfermagem 25(4): e0300015.

Rathnayake S, Athukorala Y, Siop S (2016) Attitudes toward and willingness to work with older people among undergraduate nursing students in a public university in Sri Lanka: a cross sectional study. Nurse Education Today 36(Jan): 439-444.

Ren J, Ding D, Wu Q, Liu C, Hao Y, Cui Y, Shan L (2019) Financial affordability, health insurance, and use of health care services by the elderly: findings from the China health and retirement longitudinal study. Asia Pacific Journal of Public Health 31(6): 510-521.

Sarabia-Cobo CM, Pfeiffer CC (2015) Changing negative stereotypes regarding aging in undergraduate nursing students. Nurse Education Today 35(9): e60-e64.

Seale C (1996) Living alone towards the end of life. Ageing and Society, 16: 75-91.

Smith M, Bergeron C, Cowart C, Ahn S, Towne S, Ory M et al. (2017) Factors associated with ageist attitudes among college students. Geriatrics \& Gerontology International 17(10): 1698-1706.

Söylemez B, Küçükgüçlü O, Tekin D, Ergin S, Yaman A (2018) Examining nursing students' attitudes towards the elderly and factors affecting attitudes towards the elderly. Dokuz Eylül Üniversitesi Hemşirelik Fakültesi Elektronik Dergisi 11(2): 173-179.

Toygar I, Kardakovan A (2020) Factors affecting the attitudes of nursing students toward ageism. Nursing Practice Today 7(1): 38-44.

Ulusoy MF (1998) Türkiye'de hemşirelik eğitiminin tarihsel süreci (The historical process of nursing education in Turkey). CÜ Hemşirelik Yüksekokulu Dergisi 2(1): 1-8.

Usta Y, Demir Y, Yönder M, Yildiz A (2012) Nursing students' attitudes toward ageism in Turkey. Archives of Gerontology and Geriatrics 54(1): 90-93.

World Health Organization - WHO (2020) Ageism. Retrieved from: https://www.who.int/ ageing/ageism/en/. [Accessed: 20 January 2020]

Zhang S, Liu YH, Zhang HF, Meng LN, Liu PX (2016) Determinants of undergraduate nursing students' care willingness towards the elderly in China: attitudes, gratitude and knowledge. Nurse Education Today 43(Aug): 28-33. 
